Fikrah: Jurnal Ilmu Aqidah dan Studi Keagamaan

issn 2354-6147 eissn 2476-9649

Tersedia online di: journal.stainkudus.ac.id/index.php/Fikrah

DOI: http://dx.doi.org/10.21043/fikrah.v4i2.1768

\title{
Dialektika Agama: Harmoni Dalam Jemaat Ahmadiyah (Resepsi Hermeneitis Jemaat Ahmadiyah Indonesia Manislor Kuningan Jawa Barat terhadap Ayat-ayat Jihad dan Perdamaian)
}

\author{
Adrika F. Aini \\ UIN Sunan Kalijaga \\ adrikavenny@gmail.com
}

Abdul Mustaqim
UIN Sunan Kalijaga
taqimlsq@gmail.com

\begin{abstract}
Abstrak
Perlakuan intoleransi, diskriminasi dan kekerasan sering dialami kelompok Ahmadiyah sebagai minoritas di Indonesia, tak terkecuali Jemaat Ahmadiah Manislor Kuningan beberapa tahun lalu. Fenomena seperti ini perlu mendapat konfirmasi penafsiran mengenai ayat alQur'an yang mengacu pada signifikansi nilai-nilai perdamaian yang harus dijunjung antar sesama kelompok beragama. Pasalnya, al-Qur'an juga mewacanakan pentingnya mengenai perdamaian. Reinterpretasi tersebut setidaknya dapat menjadi landasan teologis yang berguna untuk meneguhkan nilai-nilai kebebasan keyakinan beragama dan perdamaian, serta menghapuskan segala bentuk diskriminasi. Studi kasus, dengan metode deskriptif-eksplanatif melalui observasi dan wawancara mendalam, ditemukan hasil bahwa Jemaat Ahmadiyah Manislor dalam memahami ayat al-Qur'an tentang Jihad dan perdamaian ternyata mencerminkan pemahaman yang kontekstual, mereka tidak hanya memahaminya secara literal begitu saja, melainkan juga mempertimbangkan sisi historis dan konteks masa sekarang yang secara tidak sadar melibatkan horison (pre understanding) mereka. Ayat-ayat lihad dan perdamian, bagi mereka dapat menjadi solusi dari konflik dan kekerasan yang dialami jemaat Ahmadiyah Manislor.
\end{abstract}

Kata Kunci: Harmoni, jemaah Ahmadiyah, jihad, perdamaian, resepsi 


\begin{abstract}
Intolerance actions, discrimination and violence are mainly experienced by a minority Ahmadiyah group in Indonesia, including Ahmadiyya community of Manislor Kuningan few years ago. This phenomenon needs to get confirmation of the interpretation of the Qur'an verses referring to the significance of the values of peace which must be upheld between the members of religious groups. The Qur'an also explains the importance of peace. The reinterpretation of the theological foundation at least can be useful to reinforce the values of peace and religious belief freedom, and eliminate all forms of discrimination. This study belongs to descriptive and explanative method. Through observation and interviews, it was found that the Ahmadiyyah Community of Manislor in understanding the Qur'an verses about Jihad and peace has turned out to reflect contextual understanding, they do not only understand it literally, but also consider the historical and present context are unknowingly involve the horizon (pre understanding). The verses of Jihad and peace can be the solution of the conflict and violence experienced by Ahmadiyah Community of Manislor.
\end{abstract}

Keywords: Harmony, Ahmadiyah Community, Jihad, Peace, Receptions.

\title{
Pendahuluan
}

Dalam konteks masyarakat multikultural, seorang penganut suatu agama, biasanya memiliki sikap keberagamaan, sesuai dengan kedalaman pemahaman keagamaannya. Ia bisa menjadi seorang yang konservatif-radikal, moderat-inklusif atau bahkanliberal-pluralis terhadap kelompok atau agama lain. Kebenaran suatu agama adalah mutlak karena bersumber dari Tuhan, namun mengalami pergeseran apabila produk agama yakni wahyu sudah bersentuhan dengan manusia. Maksudnya adalah bahwa aspek eksoterik agama terpisah dari aspek esoterik (Schuon, 2011, hal. 160) Dalam Islam, aspek esoterik disebut dengan tasawuf, yakni sebagai wujud etis yang berakar dari ihsan. Sedangkan eksoterik, yaitu berupa aspek-aspek termasuk ilmu pengetahuan yang dapat diketahui oleh semua orang. Keduanya merupakan hasil kebudayaan yang mesti diperkuat sebagai refleksi penghambaan manusia kepada Allah. Sejauh manapun seseorang melangkah, ia tetap harus berpegang teguh kepada agama yang dianutnya sambil diharapkan bersikap kooperatif terhadap permasalahan hubungan keberagamaan antar umat. Maka diperlukan objektifitas dan historisitas, bukan semata-mata normatifitas, apalagi yang berkaitan dengan upaya meneguhkan rekonsiliasi dan harmoni antar umat beragama.

Beberapa pernyataan diatas merupakan suatu refleksi darifenomena-fenomena yang terjadi akhir-akhir ini, di mana banyak terjadi "emosi yang berlebihan" dalam 
beragama, klaim kebenaran (truth claim), benturan antar penganut agama, dan juga gesekan agama versus politik, serta yang lainnya. Maka diperlukan suatu pergeseran paradigma yang mampu mengelola dan melakukan rekonsiliasi, agar dalam tercipta harmoni sosial dalam masyarakat yang multikultural.

Usaha rekonsiliasi akan lebih memperjelas bahwa Islam memiliki sumberdaya perdamaian dan mampu bekerjasama dengan kelompok lain untuk membangun perdamaian (Johansen, 1997, hal. 67). Ide tentang peace building dalam Islam adalah ide untuk menciptakan kondisi di mana kehidupan tanpa kekerasan (nonviolence). Hubungan antar kelompok agama pada dasarnya merupakan bentuk lain dari hubungan antar manusia. Realitas sosial telah membuktikan, manusia memiliki ikatan keterpengaruhan dengan nilai-nilai tertentu yang berkembang pada suatu kawasan di manapun ia hidup. Nilai tersebut membentuk pola pikir dan pola perilaku manusia (local wisdom). Nilai-nilai tersebut diperoleh dari pemahaman suatu masyarakat terhadap penafsiran al-Qur’an.

Sudut pandang seperti ini mensiratkan bahwa anggota kelompok agama dalam masyarakat dalam suatu sistem interaksi yang terintegrasi ke dalam suatu bentuk equilibrium. (Nasikun, 1995, hal. 9) Agama menunjukkan peran fungsinya ketika agama memberikan perubahan pada komunitas itu dan memberikan warna baru dalam masyarakat. Keyakinan akan kebenaran ajaran agama akan mendorong manusia sebagai elemen pokok dalam masyarakat akan bersikap sesuai ajarannya. Tentu hal ini akan mempengaruhi pandangan hidup dan budayanya, yang akan terekspresi dalam laku kehidupannya.

Konflik dan cara penyelesaiannya dalam masyarakat Manislor Kuningan dalam hal ini menarik untuk diteliti, bagaimana agama dijadikan landasan dalam kehidupan yang harmonis, dan bagaimana upaya rekonsiliasi yang berlandaskan pemahaman ayat al-Qur'an tersebut mereka wujudkan dalam kehidupan kesehariannya. Dalam melakukan rekonsiliasi, jemaat Ahmadiyah Manislor memiliki kemampuan menjalin ukhuwah basyariyah (persaudaraan sesama manusia).

Dari hal tersebut, penelitian ini fokus pada kepercayaan keagamaan yang mereka aplikasikan dalam kehidupan keseharian mereka, yang disebut dengan kajian resepsi. Penelitian ini akan mengungkap tentang bagaimana upaya rekonsiliasi jemaat Ahmadiyah Manislor Kuningan? Bagaimana pula wujud resepsi dan internalisasi ayat-ayat jihad dan perdamaian yang berimplikasi dalam penyelesaian konflik? Dari pemahaman ayat al-Qur'an tersebut berimbas pada kemajemukan institusi sosial pada masyarakat yang merupakan salah satu media relevan untuk memperkuat hubungan antar kelompok masyarakat. Kuatnya pemahaman mereka terwujud dalam integrasi sosial yang dibangunnya, di mana integrasi merupakan pengendalian terhadap konflik dan penyimpangan dalam suatu sistem sosial. (Soekanto, 1983, hal. 157) Integrasi sosial dimaksudkan sebagai penyatuan kelompok-kelompok yang sebelumnya terpisah satu sama lain melalui upaya melenyapkan perbedaanperbedaan sosial. 
Proses terjadinya integrasi melalui suatu tahapan, yakni integrasi interpersonal dan adanya komunikasi kontak sosial (social contact) merupakan syarat mutlak terjadinya integrasi. Ketika terjadi kontak sosial dan komunikasi di antara individu, maka akan berlanjut dengan saling merespon antar kelompok. Dalam pandangan teori fungsional struktural terdapat dua hal yang melandasi terjadinya integrasi suatu sistem sosial, yaitu pertama suatu masyarakat terintegrasi di atas tumbuhnya konsensus di antara norma-norma kemasyarakatan yang bersifat universal dan fundamental, kedua, karena bermacam-macam anggota masyarakat sekaligus menjadi anggota dari berbagai kesatuan sosial (cross cutting loyalities) (Nasikun, 1995, hal. 69).

Secara esensial prinsip-prinsip pokok fungsionalisme struktural menurut Stephen K. Anderson adalah:

1. Masyarakat merupakan sistem yang kompleks terdiri dari bagian-bagian yang saling berhubungan dan saling bergantung, setiap bagian saling berpengaruh secara signifikan terhadap bagian-bagian lainnya.

2. Setiap bagian dari sebuah masyarakat eksis karena bagian tersebut memiliki fungsi penting dalam memelihara eksistensi dan stabilitas masyarakat secara keseluruhan.

3. Semua masyarakat memiliki mekanisme untuk mengintegrasikan dirinya, yaitu mekanisme yang dapat merekatkannya menjadi satu. Salah satu bagian penting dari mekanisme ini adalah komitmen para anggota masyarakat kepada serangkaian kepercayaan dan nilai yang sama.

4. Masyarakat cenderung mengarah pada satu kesatuan equilibrium atau homoestatis dan gangguan pada salah satu bagian cenderung menimbulkan penyesuaian pada bagian lain agar tercapai harmoni dan stabilitas.

5. Perubahan sosial merupakan kejadian yang tidak biasa dalam masyarakat tetapi apabila terjadi juga maka perubahan itu pada umumnya akan membawa kepada konsekuensi-konsekuensi yang menguntungkan masyarakat secara keseluruhan.

Dari penjelasan tersebut, penelitian ini sangat menarik untuk dilakukan dengan menggunakan penelitian lapangan yang bersifat kualitatif dengan metode indepth interview.

\section{Ekstraksi Konflik Ahmadiyah Manislor}

Ahmadiyah masuk Desa Manislor pada tahun 1954 yang dibawa oleh salah satu warga Manislor, yakni Bening yang membawa paham Ahmadiyah dan mendakwahkan kepada penduduk Manislor. Setelah itu diminta seorang tokoh Ahmadiyah datang ke Manislor untuk memberikan pemahaman kepada masyarakat pada saat itu, yakni Haji Basyari Hasan (Tisnaprawira, 2012). Setelah pertemuan Juandi, Bening, dan Haji Basyari, Ahmadiyah mulai dikenal oleh penduduk Manislor. 
Setelah mulai dikenal di penduduk Manislor mengenai pemahaman kedatangan Imam Mahdi, maka banyak masyarakat yang masuk dalam jemaat Ahmadiyah. Baiat awwalin pada tahun 1954 hampir penduduk Manislor yang berjumlah 262 dibaiat menjadi anggota jemaat Ahmadiyah. Setelah itu Manislor mulai dihuni oleh jemaat Ahmadiyah dan aktivitasnya. Akan tetapi, setelah proses panjang berdirinya jemaat Ahmadiyah Manislor dari tahun 1954 diawal memang sudah terjadi konflik yang mengakibatkan beberapa jemaat keluar dari Ahmadiyah. Banyak larangan yang ditujukan kepada para jemaat Ahmadiyah, yakni larangan shalat di masjid Desa dan lain sebagainya. Setelah proses konflik tersebut, kondisi Manislor aman dan tenteram yakni pada tahun 1954-1984. Pada tahun 1984 mulai ada fatwa MUI yang mengakibatkan hinaan terhadap kelompok tersebut dan coretan-coretan di mana-mana menghujat Ahmadiyah. Proses rekonsiliasi saat itu dengan dialog yang dilakukan oleh bapak Bupati Kuningan. Sehingga pada tahun 1985 sampai 2000 awal kondisi kembali aman dan tenteram. Pada tahun 2000 ketegangan mulai terjadi kembali, yakni penyerangan di balai Desa Maniskidul yang menyebabkan 1 masjid dibakar dan perusakan 1 mushalla. Setelah itu, konflik mulai terjadi sampai tahun 2010. Baik yang berwujud penyerangan pada rumah-rumah jemaat ataupun melakukan aksi pemberontakan dengan mencoret-coret, membakar ban, sampai pembakaran masjid Ahmadiyah. Adapun konflik yang terjadi di Desa Manislor tersebut dapat dibagi menjadi tiga tipe, yakni:

Pertama, adalah lokalitas. Pada tipe yang pertama ini terjadi pada tahun 2002-2004. Penyerangan yang dilakukan oleh sekelompok massa yang merupakam masyarakat Manislor dan sekeliling Desa sendiri. Penyerangan tersebut selalu dilakukan pada malam hari. Sebagaimana tragedi yang terjadi pada tanggal 18 september 2002, jemaat Ahmadiyah Manislor mendapat surat peringatan akan pelarangan kepada jemaat yang ditanda tangani oleh Ormas RUDAL, MUI Manislor, dan DKM Masjid al-Huda.

Setelah 1 bulan kemudian, Ormas RUDAL melakukan penyerangan dengan merusak kaca masjid at-Taqwa dan perusakan rumah bu Jaetun (anggota jemaat). Selain itu pada dekade saat itu terjadi juga penyerangan masjid al-Hidayah, puluhan rumah anggota jemaat menjadi sasaran. Penyerangan mayoritas dilakukan pada malam hari, yakni mulai pukul 23.00. Oleh karena itu, pada era ini disebut dengan konflik lokal.

\section{Politik Dalam}

Pada tipe konflik yang kedua ini, bahwa konflik yang terjadi merupakan ada unsur politik di dalamnya. Tipe ini terjadi pada tahun 2004-2007. Pada tahuntahun ini mulai bermunculan ormas-ormas dari manislor atau kuningan sendiri yang menyerang jemaat Ahmadiyah Manislor. Beberapa ormas yang melakukan penyerangan adalah di antaranya Gamas (Gerakan Anti Maksiat), Barat (Barisan Anak Kuningan), Gibas (Gerakan Inisiatif Anak Siliwangi), dan beberapa ormas lainnya.

Tipe ini disebut sebagai politik dalam, karena penyerangan yang dilakukan merupakan ada backup politik. Karena, pada saat itu ada momen pilkada. Pada era 
ini, tidak hanya terjadi penyerangan pada jemaat Ahmadiyah, akan tetapi juga mulai ada penekanan kepada pemerintahan. Ormas mendekati pemerintahan untuk mulai melakukan penekanan pada jemaat Ahmadiyah, yakni dengan mengadakan dialog dengan beberapa badan pemerintahan, seperti DPRD, Bupati, atau Parpol. Misalnya saja pada tanggal 22 Oktober 2005 terdapat dialog antara jemaat Ahmadiyah dengan MUI yang difasilitasi oleh Pemda, jemaat Ahmadiyah mendapat undangan dari Camat Jalaksana untuk melakukan pertemuan di Kecamatan. Selain itu, para ormas tersebut banyak mengirim surat kepada pemerintahan perihal pelanggaran Ahmadiyah, seperti kepada KAJARI, KAPOLRES, dan lembaga pemerintahan yang lainnya.

\section{Politik Luar}

Pada tipe yang ketiga ini, yakni pada tahun 2007-2010 konflik mulai terjadi bukan hanya dari kelompok dalam sendiri, akan tetapi konflik dan penyerangan sudah mulai dilakukan oleh kelompok luar Manislor dan Kuningan. Menurut penuturan kepala Desa Manislor bahwa penyerangan yang terjadi sudah tidak dari masyarakat sendiri, akan tetapi dari kelompok luar seperti dari Cirebon, Indramayu, dan beberapa daerah lain di Jawa Barat.

Pada era ini mulai muncul SKB III Menteri. Sehingga, konflik yang terjadi pada era ini bukan hanya menyangkut Manislor saja, akan tetap sudah masuk pada wilayah tataran hukum. Banyak dilakukan dialog antara jemaat Ahmadiyah dengan pemerintahan, baik Bupati, Kapolres, Dandim, Babinsa, dan juga sampai pada Kementrian Agama RI. Ormas yang mulai masuk dalam ancaman dan penyerangan terhadap jema’at Ahmadiyah Manislor, yaitu dari FPI, seperti ancaman yang datang dari Habib Riziq pada tanggal 6 Agustus 2010.

\section{Resepsi Sebagai Arah Baru Kontekstualisasi Pembumian Al-Qur'an}

Ruang lingkup penelitian ini ada pada wilayah kajian resepsi pembaca terhadap teks. Dalam hal ini teks yang diresepsi adalah teks ayat al-Qur'an. Oleh karena itu, fokus kajian ada wilayah resepsi pembaca, khususnya resepsi pembaca terhadap ayat-ayat perdamaian. Resepsi yang dimaksud adalah resepsi hermeneutis, yaitu resepsi yang diaktulisasikan dalam pemahaman dan tindakan. Kajian difokuskan pada resepsi pembaca terhadap penafsiran Jemaat Ahmadiyah Indonesia Manislor Kuningan. Untuk mengungkapkan fokus tersebut digunakan perpaduan dua perspektif, yaitu resepsi terhadap teks dan hermeneutika. Resepsi teks digunakan sebagai dasar teoretis untuk menemukan/menentukan ontologi kajian resepsi yang berfokus pada pembaca. Perspektif hermeneutika digunakan sebagai dasar epistemologi untuk memahami dan menjelaskan proses penafsiran, terutama penafsiran peneliti terhadap teks yang meliputi dua kategori teks, yaitu teks resepsi (utama) dan teks ayat-ayat jihad dan perdamaian(teks sebagai konteks teks utama),namun juga dipertimbangkan teks-teks lain yang relevan. 
Teknik interpretasi terhadap teks resepsi untuk memperoleh interpretasi yang memadai (sesuai dengan tujuan penelitian), digunakan teknik lingkaran hermeneutis. Ibrahim menjelaskan bahwa seorang interpreter memandang suatu teks khusus berdasarkan gagasan umum tentang apa yang mungkin dimaksudkan teks itu, kemudian memodifikasi ide umum itu berdasar pemeriksaan terhadap ciriciri khusus teks. (Ibrahim, ttt, hal. 11) Selanjutnya, dalam putaran hermeneutika itu selalu menghubungkan apa yang dilihat dalam objek itu dengan apa yang diketahui. Interpreter kemudian bergantian beralih antara seperangkat konsep yang dikenal dengan yang tak dikenal sampai keduanya menyatu dalam suatu interpretasi tentatif.

Berbicara tentang resepsi al-Qur'an, maka perlu melakukan konfirmasi tentang pengertian operasioanal resepsi al-Qur'an dalam tulisan ini. Apa yang dimaksud dengan resepsi atau penerimaan adalah bagaimana seseorang menerima dan bereaksi terhadap sesuatu. Jadi resepi adalah uraian bagaimana orang menerima dan bereaksi terhadap al-Qur'an dengan cara menerima, merespon, memanfaatkan, dan menggunakan baik sebagai teks yang memuat susunan sintaksis atau sebagai mushaf yang dibukukan yang memiliki maknanya sendiri atau sekumpulan katakata lepas yang mempunyai makna tertentu. (Sahiron dkk, 2012, hal. 73) Resepsi terhadap al-Qur'an sebagai sekumpulan teks berbahasa Arab, secara umum, telah merangkum dalam sejarah penafsiran al-Qur'an. Sekalipun demikian, ini pun masih tergantung pada pendekatan dan metodologi yang digunakan untuk menentukan diterima atau ditolaknya sebuah penafsiran.

Oleh karena itu, resepsi al-Qur'an dari satu generasi terdahulu sangat mungkin untuk ditiru secara kreatif oleh generasi-generasi selanjutnya, tergantung pada transmisi pengetahuan yang berlangsung serta model resepsinya apakah melalui teks atau praktik. Berbicara mengenai resepsi, maka akan membicarakan pula mengenai transmisi dalam teks al-Qur'an, baik berupa ayat-ayat al-Qur'an sendiri, Hadis, atau karya yang menggambarkan praktik resepsi tersebut.

Dengan itu, dalam resepsi teks itu dapat bermakna bukan hanya dari pemahaman normatif, akan tetapi peran pembaca juga mempengaruhi makna yang muncul yang kemudian menimbulkan suatu praktik. Pembaca mempunyai peran yang penting dalam hal ini karena pembaca merupakan pembalikan paradigma secara total, pembaca yang sama sekali mengetahui tentang proses kreatif diberi fungsi utama, sebab pembacalah yang menikmati, menilai, dan memanfaatkannya. Sebaliknya, penulis sebagai asal-usul karya harus tersingkirkan, bahkan dianggap sebagai anonimitas (Ratna, 2006, hal. 169).

Setiap pembaca mempunyai horison harapan yang berbeda-beda. Horison harapan atau cakrawala harapan (horizon expectation) adalah harapan-harapan seorang pembaca terhadap suatu teks. Setiap pembaca mempunyai konsep atau pengertian tertentu mengenai sesuatu. (Jauss, ttt, hal. 141) Cakrawala harapan seseorang itu ditentukan oleh pendidikan, pengalaman, pengetahuan, dan 
kemampuan menanggapi sebuah peristiwa. Erat kaitannya dengan pemaknaan teks, makna horison harapan memainkan peran penting. Horison harapan ini terbentuk dalam tiga kriteria, pertama, pengetahuan pembaca tentang norma atau suatu genre. Kedua, pengetahuan dan pengalaman pembaca tentang teks-teks yang telah dibacanya. Ketiga, perbedaan antara fiksi dan realita, yaitu tentang perbedaan antara horison harapan yang "sempit" dan horison harapan yang "luas".(Rien, ttt, hal. 141) Horison harapan ini bercerita tentang bagaimana sebuah teks dinilai dan ditafsirkan, bukan bagaimana ia ditentukan maknanya, sebagaimana ungkapan Gadamer. Dari situlah, maka memunculkan pluralitas makna, karena setiap pembaca berangkat dari horison harapannya masing-masing.

Sehingga, objek dari resepsi al-Qur'an mempunyai beberapa bentuk, yakni dari pembacaan kepada penulisan teks al-Qur'an, dari sebuah doa menjadi suatu yang dipakai perlindungan, dari hafalan menjadi susunan kata, dari buaian menjadi keseriusan. Sehingga, dari suatu kelompok umat Islam bahwa resepsi al-Qur'an terbagi menjadi dua bentuk, yakni teologi dan histori. (Rafiq, 2015) Resepsi, bukan hanya bagaimana umat Islam memahami suatu teks al-Qur'an, akan tetapi bagaimana umat Islam memberi asumsi -dan merasakan- teks al-Qur'an sebagai suatu kitab suci yang mempunyai arti dalam kehidupan.

Ketika muslim merasakan hasil dari ayat al-Qur'an, mereka tidak hanya mempunyai keterkaitan dengan makna literer teks, akan tetapi juga bergantung pada makna yang dilihat dari suatu peristiwa yang berhubungan langsung pada masa lalu (hibrid) atau yang tidak langsung berhubungan dengan makna teks tersebut. Untuk mengetahui resepsi yang terjadi di dalam pemahaman teks al-Qur'an, maka ada tiga bidang yang untuk melihat studi resepsi al-Qur'an tersebut, yakni Origin(pendekatan kritik sejarah kepada al-Qur'an), form and meaning (penafsiran dan pendekatan hermeneutik kepada teks al-Qur'an), serta function (pendekatan fenomenologi).

\section{Meaning Function Ayat-Ayat Jihad Dan Perdamaian}

Al-Qur'an surat al-Hajj (22) : 39-40, di mana Nabi dan para pengikutnya pada waktu itu mulai diizinkan untuk pergi berperang harus dipahami berdasarkan konteks tekstual dan historisnya. Berbasis pada dua konteks tersebut, seseorang bisa mengatakan bahwa pesan utama dari ayat-ayat ini bukanlah pergi berperang itu sendiri, akan tetapi menghapus penindasan dan menegakkan kebebasan beragama dan perdamaian. Dengan kata lain, perang hanyalah sebuah alat untuk mewujudkan nilai-nilai moral tersebut. Ini berarti bahwa perang harus dihindari jika masih ada jalan atau cara tanpa kekerasan (non-violent actions) yang masih mungkin dilakukan. Salah satu muballigh di Manislor meresepsi ayat tersebut bahwa itu merupakan jihad kecil, serta ayat tersebut bukan inti utamanya sebagai kewajiban berperang. Sebagaimana yang diungkapkan oleh Pak Aang:

"ayat tersebut memang perintah untuk berperang, akan tetapi pada saat itu konteks yang terjadi memang menghadapi kaum musyrik atau musuh. Namun, apabila kita menarik pemahaman tersebut dalam konteks penyerbuan kepada jemaat Ahmadiyah Manislor ini, mereka bukanlah orang musyrikin. Dan 
sebab penyerangan tersebut karena kesalahpahaman, sehingga perlawanan atau berperang tidak dibolehkan pada saat itu."

Resepsi ayat tersebut juga harus dipahami dalam konteksnya, sebagaimana pula dalam pernyataan Nashiruddin, bahwa pada zaman Nabi ada dua era, yakni Ghazwah dan Ghair Ghazwah. Pada saat era ghazwah, dibutuhkan suatu peperangan untuk mempertahankan eksistensi umat Islam, yang mana tujuan perang bukan untuk ekspansi atau membantai seseorang, akan tetapi untuk mempertahankan aqidah Islam yang diganggu oleh kaum musyrikin. Sedangkan era ghair ghazwah, yaitu pada saat suasana kondusif. Nashiruddin memisalkan pada saat Fathu Makkah. Ia mengatakan;

"Pada saat itu umat Islam mengalami kemenangan. Nabi menunjukkan akhlak baik kepada masyarakat, dan pada saat itu orang Musyrik ada yang berkata agar Muhammad bertindak seperti Nabi Yusuf kepada mereka, 'memaafkan'. Dan nabi pun menunjukkan kemuliaanya untuk memaafkan mereka" (Lings, 1983, hal. 41-42).

"Nabi saat melakukan perjalanan ke Thaif dan Nabi mendapat gangguan salah satu penduduk Thaif, yakni Nabi dilempari batu, maka Nabi berdo'a: Allah Mahdi Fainnahu La Ya'lamun. "Ya Allah berikan petunjuk kepada kaum yang tidak mengetahui, semoga ada anak turunnya yang beriman kepada Engkau Ya Allah.”

Apa yang dilakukan oleh Nabi ini merupakan contoh bagaimana konflik sesungguhnya bisa diatasi tanpa ada kekerasan. Dari tindakan nabi tersebut ada beberapa nilai inti yang bisa diidentifikasi untuk menciptakan perdamaian menurut Nashiruddin. Sebagaimana dalam bahasa Martin Luther yakni egape, yakni suatu pencarian aktif untuk melindungi dan menciptakan komunitas (Luther, 1958, hal. 87).

Di sini, pernyataan anggota jemaat tersebut seperti yang dikatakan Syahrur dalam Tajfif Manabi' al-Irhabbahwa: “jihad (usaha) dalam di jalan Allah boleh diikuti dengan peperangan hanya dalam situasi yang sangat diperlukan agar seluruh umat manusia mendapatkan kebebasan memilih (hurriyyat al-ikhtiyar) yang aspek utamanya adalah kebebasan beragama, berekspresi, menggunakan simbol keagamaan, sekte, keadilan dan kesetaraan" (Syahrur, 2008, hal. 138).

Karena itu, masyarakat jemaat Ahmadiyah Manislor meresepsi QS 2:190:

"bahwa ayat tersebut memerintahkan kepada Nabi dan para sahabatnya untuk tidak membunuh kaum kafir yang dalam keadaan tidak siap berperang dan mereka yang menyerah secara damai kepada kaum muslimin. Diriwayatkan bahwa terkait makna ayat ini, Ibn 'Abbas menyatakan: "Jangan membunuh perempuan, anak-anak, orang-orang yang sudah tua, dan mereka yang menyerah kepadamu dengan damai."

Dengan melarang mereka membunuh kaum yang 'lemah', jelas bahwa membunuh kaum kafir bukanlah tujuan utama dari perang. Pada saat perang pun, 
Nabi dan para sahabatnya hanya diperbolehkan untuk membunuh kaum kafir yang melakukan penindasan kepada kaum muslimin, mereka yang tidak menerima pluralisme agama dan mereka yang tidak mau menegakkan perdamaian.

\section{Penghapusan Penindasan}

Penindasan atau dalam bahasa Arab, zhulm, dianggap sebagai tindakan immoral dalam Islam. Ada banyak ayat yang mengutuk mereka yang memiliki karakter ini. Secara leksikal, kata ini dalam Lisan al-'Arab bermakna wad' al-syai'i fi ghairi mahallihi (menempatkan sesuatu tidak pada tempatnya). Dalam al-Quran, kata ini digunakan sebagian besar merujuk kepada sikap yang bertentangan dengan hukum Allah. Tindakan yang paling buruk adalah syirk (politeisme) sebagaimana disebutkan dalam QS. al-An’am (6): 82 dan QS. Ali Imran (31): 13. Arti lain dari kata ini adalah melakukan sebuah tindakan yang menyakiti seseorang, hak dan hak miliknya. Makna yang demikian ini relevan untuk konteks QS.al-Hajj (22): 39 udzina li-lladzina yuqataluna bi-annahum zhulimu. Dalam pengertian ini, level tertinggi dari zhulm adalah mengusir seseorang dari tanahnya, sebagaimana disebutkan dalam QS. al-Hajj (22): 40. Sekali lagi, pengizinan berperang bukanlah pesan utama dari ayat ini. Ayat ini lebih bermakna bahwa Tuhan membenci penindasan dan manusia haruslah mencegah diri mereka sendiri dari tindakan yang semacam ini. Jika seseorang ditindas, maka dia punya hak untuk mempertahankan diri, atau dengan kata lain, mereka diizinkan untuk berperang melawan para penindas tersebut. Selain itu, ayat ini juga berarti bahwa jika masih ada solusi damai untuk masalah ini, manusia harus menghindari melakukan peperangan. Pernyataan tersebut disampaikan oleh Nashiruddin dengan juga menyebut hadis Nabi:

"Orang yang kuat itu bukan orang yang kuat ototnya, akan tetapi orang yang kuat adalah orang yang bersabar ketika tertimpa suatu musibah."

\section{Penegakan Kebebasan Beragama}

Pesan utama kedua adalah kebebasan beragama. Al-Qur'an menekankan pentingnya hak memilih dan kebebasan manusia dalam berkeyakinan. QS. 2: 256 menyebutkan bahwa tidak ada paksaan dalam agama. Izin melakukan peperangan pada masa Nabi diberikan adalah untuk tujuan penegakan kebebasan beragama. Kaum kafir Makkah tidak memberikan kebebasan kepada masyarakat, sebagaimana ditunjukkan oleh QS. 22: 40. Namun demikian, untuk menegakkan kebebasan beragama, manusia tidak harus pergi berperang, jika ada jalan damai lain. Jalan damai ini juga dilakukan oleh Nabi. Hal ini terdapat sinkronisasi atas pemahaman jemaat Ahmadiyah terhadap ayat tersebut, sebagaimana resepsi hermeneutis yang diungkapkan oleh beberapa muballigh Ahmadiyah Manislor,

"Diriwayatkan bahwa pada tahun ke-6 H ketika dilakukan perjanjian Hudaibiyah, Nabi dan para sahabatnya ingin menjalankan ibadah umrah, akan tetapi kaum musyrik menghalangi mereka. Setelah melakukan komunikasi diplomatis, kedua belah pihak sampai kepada kesepakatan bahwa muslim boleh menjalankan ritual keagamaan pada tahun ke-7 H.” 


\section{Penegakan Perdamaian}

Penegakan perdamaian adalah salah satu pesan utama dari pembolehan melakukan perang. Perang adalah alat untuk mewujudkan perdamaian, akan tetapi bukan satu-satunya jalan. Karena itu, selama manusia bisa mewujudkan perdamaian tanpa peperangan, mereka tidak diperbolehkan berperang. Islam mengkampanyekan sikap damai kepada seluruh manusia tanpa memperhatikan keragaman agama dan budaya mereka. Sikap damai telah dilakukan Nabi dan para pengikutnya di Madinah, di mana mereka dan masyarakat dari agama lain, seperti Yahudi dan Kristen, hidup berdampingan dalam harmoni. Ada juga ayat lain, sebagaimana disebutkan sebelumnya, yang memerintahkan umat Islam untuk menjaga perdamaian. Atas dasar ini, Nashiruddin dan Aang mengutip ayat yang secara eksplisit menjelaskan mengenai peperangan akan tetapi ada hal yang seharusnya diambil dari QS. al-Hajj 22: 39-40 adalah bukan kebolehan berperangnya, akan tetapi pesan perdamaiannya. Hal ini juga diiringi oleh pemahaman mereka atas pemaparan khalifah IV dalam menciptakan perdamaian, yakni

"kami akan beli hati orang Eropa dengan cara menampilkan akhlak Nabi pada mereka dan tidak menampilkan kelemahan Islam pada mereka, karena nabi itu diutus untuk menyempurnakan akhlak, bukan untuk melakukan peperangan."

Dari beberapa pemaparan yang disampaikan oleh para jemaat Ahmadiyah di Manislor Kuningan tersebut, dapat dilihat bahwa masyarakat Ahmadiyah telah meresepsi ayat al-Qur'an yang dipraktikkan dalam penyelesaian konflik yang terjadi pada diri mereka. Proses resepsi tersebut baik ditunjukkan dengan bentuk hibridatau sejarah historis yang berhubungan langsung (directly) maupun sejarah yang tidak langsung berhubungan (indirectly). Para jemaat Ahmadiyah di Desa tesebut dalam proses rekonsiliasi menghadirkan cara resepsi secara hermeneutis terhadap ayat-ayat perang. Mereka yang sebelumnya pasti mempunyai horison harapan atau dalam bahasa Gadamer adalah pre-understanding yang membentuk pikiran seseorang atau sekelompok orang dengan pengalamannya masing-masing. Sebagaimana dalam pemahaman ayat jihad dan perdamaian, jemaat Ahmadiyah sebelum mengetahui makna dari ayat tersebut, mereka telah dikonstruk pikirannya dengan pengetahuan mereka tentang jihad, perang, dan perdamaian. Sehingga, dalam memahami ayat tersebut horison harapan itu akan dibawa dalam proses resepsinya, baik dari pengetahuannya dari sabda-sabda khalifah dan buku-buku pemahaman Ahmadiyah.

Melihat pemahaman yang dihadirkan oleh jemaat Ahmadiyah dalam proses rekonsiliasi tersebut, ada proses transmisi dan transformasi sehingga membentuk pemahaman atas ayat-ayat jihad dan perdamaian tersebut. Apabila dilihat dari hasil resepsi yang dilakukan, maka jemaat Ahmadiyah dapat dibilang melakukan resepsi secara hermeneutis yang subjektifis (Sahiron, 2011, hal. 25). Secara tidak langsung para jema'at Ahmadiyah telah menggunakan model penafsiran hermeneutik yang dalam memahami ayat al-Qur'an tidak hanya hubungan vertikal antara Tuhan dan teks, akan tetapi mereka telah menerapkan lingkaran hermeneutika-author, teks, reader, context. 


\section{Rekonsiliasi Dalam Jemaat Ahmadiyah Indonesia Manislor}

Pada sub bab ini, juga akan menjelaskan faktor-faktor yang menjadikan masyarakat Manislor dapat meredam atau menyisikan munculnya konflik pasca 2010 berulang yang bersifat manifes-destruktif terhadap isu-isu ketegangan, sentimensentimen, sehingga terjadi dinamika keberagaman masyarakat. Ada beberapa faktor peredam konflik terbuka (manifes-destruktif) dalam masyarakat Manislor Kuningan. Beberapa faktor yang mendukung tersebut adalah pertama, faktor hubungan kekeluargaan atau kekerabatan, kedua, adanya sistem sosial, kegiatan sosial menjadi sarana ruang publik masyarakat Manislor, ketiga, keseimbangan peranan masyarakat elit atau tokoh agama dalam struktur pemerintahan Desa sehingga menciptakan kohesi dan sekaligus menjadi keteraturan di antara masyarakat Manislor.

Faktor tersebut sangat berpengaruh dalam menjembatani aktivitas sosial atau interaksi sosial yang kemudian melahirkan solidaritas dan harmonisasi dalam kehidupan bermasyarakat. Keragaman aktivitas dan bentuk solidaritas tersebut mempengaruhi kualitas dan jalinan hubungan antara anggota-anggota kelompok dalam masyarakat, sehingga dapat meredam atau menekan munculnya konflik pasca peristiwa konflik beruntun yang bersifat destruktif. Adapun faktor-faktor yang membangun adanya proses rekonsiliasi tersebut adalah:

\section{Hubungan Kekerabatan}

Faktor utama masyarakat Manislor dapat meredam konflik terbuka dan membangun pola relasi menuju keseimbangan kehidupan yang guyub dan rukun adalah adanya ikatan kekerabatan atau kekeluargaan. Faktor ini yang mendukung pemahamannya terhadap toleransi dapat dikuatkan dan juga dapat mendorong sikap inklusif dalam kehidupan mereka dalam ruang lingkup lokal. Meskipun dalam lingkungan kelurahan Manislor, memiliki tetangga Desa yang tidak hanya dihuni oleh Jema'at Ahmadiyah saja, akan tetapi terdiri dari berbagai macam ideologi keagamaan, namun secara umum mereka masih mempunyai hubungan kekerabatan. Kuatnya hubungan kekeluargaan ini dapat dilihat dari pernyataan Pak Aang:

"Meskipun kita sering mendapat penyerangan dari kelompok-kelompok radikal, dan konflik yang berkepanjangan, namun kita bisa damai dalam interaksi keseharian. Lihat saja ke sawah, disana masyarakat jemaat maupun ghair bisa bercanda bersama-sama tanpa ada ketegangan konflik yang sedang terjadi."

"Kita masyarakat yang bertetangga dekat dengan orang Ahmadiyah, namun kita tidak pernah mencampuri urusan mereka dan dapat hidup rukun dan damai meskipun berbeda ideologi keagamaan, namun kita tetap Islam. Dan yang sangat dapat menyatukan kita untuk selalu hidup rukun adalah keluarga. Keluarga saya NU, akan tetapi adik saya orang Ahmadiyah di sana, namun kita tidak pernah berselisih dalam masalah perbedaan tersebut."

Ikatan kekeluargaan yang demikian memperlihatkan akan adanya interaksionisme bahwa setiap individu memiliki pemaknaan sendiri berdasarkan 
simbol makna yang diterimanya, atau individu tersebut memiliki otoritas untuk mengatur tindakannya sendiri (Ritzer, 1985, hal. 60). Sikap saling menghormati antar kelompok keagamaan masyarakat Manislor ini menjadi pondasi penting dalam kehidupan sosial bermasyarakat. Kesadaran untuk hidup bersosial antar sesama warga mendorong terbangunnya solidaritas di antara masyarakat Manislor Kuningan.

Selain bentuk kekerabatan yang mengambil bentuk terhadap sikap saling menghormati, ikatan kekerabatan di antara warga juga mengambil bentuk konkrit dalam membangun interaksi sosial (social interaction) yang dalam kehidupan masyarakat Manislor disebut saling berkunjung. Budaya ini merupakan bentuk tindakan saling bertemu ke rumah tetangga dan kerabat, baik sesama kelompok maupun ghair (kelompok non Ahmadi). Interaksi sosial ini merupakan hubungan yang dinamis, yang menyangkut kesadaran akan pentingnya membangun pergaulan hidup dalam bermasyarakat. Sebagaimana penuturan tokoh NU Kuningan yang menyebutkan:

"kalau sosialnya, amalan-amalan kebaikannya tidak disangsikan lagi lah kalau para Jemaat Ahmadiyah sini. Ya yang namanya orang memang punya perbedaan keyakinan, akan tetapi dalam hubungannya dengan manusia (hablun min an-nas) tidak bisa dipisahkan. Boleh kita berbeda, akan tetapi membangun perdamaian melalui persamaan-persamaan yang ada yang diutamakan, apalagi kita masih ada hubungan darah.”

Hubungan kekeluargaan setidaknya mampu menjadi upaya proses rekonsiliasi dalam meredam emosi kemarahan yang dimunculkan dari pola relasi keberagaman yang bersifat sentimental-konfliktual. Setiap perasaan jengkel, benci dapat diminimalisasi. Implikasinya, semakin dekat hubungan maka semakin sulit rasa permusuhan diungkapkan.

\section{Kegiatan-Kegiatan sebagai Ruang Publik}

Sistem sosial, tidak hanya kumpulan individu semata, tetapi merupakan sebuah tindakan sosial di mana individu saling berinteraksi yang nantinya terwujud hubungan yang membentuk nilai-nilai hidup bersama dalam keseimbangan, yang disebut dengan "ruang publik" (public sphere). Ruang publik yang dimaksud adalah kegiatan-kegiatan sosial yang diadakan oleh Jemaat Ahmadiyah maupun pemerintahan Desa. Misalnya saja, apabila ada salah satu warga memiliki acara hajatan, maka secara tidak langsung tetangga dan keluarga baik Ahmadi maupun ghair (Non Ahmadi) memiliki kewajiban untuk membantunya tanpa mempersoalkan latar belakang keyakinan yang akan melaksanakan hajatan tersebut. Di dalam acara seperti itulah terjadi perjumpaan dan interaksi antar masyarakat Manislor, saling berinteraksi tanpa ada gap-gap (pemisahan) antara kelompok keagamaan.

Jema’at Ahmdiyah Manislor Kuningan sangat terbuka demi berlangsungnya suatu perdamaian di antara mereka. Banyak kegiatan yang sering dilakukan oleh 
jemaat Ahmadiyah Manislor yang melibatkan para ghair (Non Ahmadi) guna sebagai proses pengenalan Ahmadiyah di ruang umum agar tidak terjadi konflik kembali. Jemaat Ahmadiyah Manislor memiliki kegiatan rutin donor darah. Kegiatan tersebut tidak hanya untuk para jema'at akan tetapi ditujukan pula kepada para ghair (Non Ahmadi). Sebagaimana penuturan ketua cabang Ahmadiyah Manislor yang mengatakan:

"kami selalu berupaya untuk terjalinnya kerukunan di antara warga, sehingga banyak kegiatan yang kami lakukan agar sesama warga dapat bertemu dan juga berkomunikasi, sehingga terjalin hubungan yang baik. Donor darah kita adakan rutin beberapa bulan sekali, dan disitulah kita dapat bertemu dan berkomunikasi. Al-Qur'an mengajarkan kita untuk selalu menjalin komunikasi dan perdamaian di dunia ini. Jadi, kenapa kita sebagai manusia tidak melakukannya. Dan, inilah cara kami untuk mengaplikasikan perintah Allah tersebut, yaitu melalui kegiatan-kegiatan sosial."

Hal ini sebagai bentuk keterbukaan jemaat Manislor untuk kelompok lain mengetahui Jema'at Ahmadiyah.

Dalam ruang publik tersebutlah konstruksi dialog dalam struktur masyarakat Manislor berlangsung, sehingga satu sama lain memahami realitas pluralitas kehidupan keberagaman yang akan mendorong ke arah keseimbangan dalam membangun kehidupan yang damai dan saling memahami. Sehingga, konflik yang bersifat manifes-destruktif dapat diredam pasca bentrokan 2000-2010.

\section{Peran Tokoh Masyarakat Sebagai "Social Control”}

Pemerintahan Desa merupakan lembaga yang dekat dengan kehidupan masyarakat. dalam konteks inilah peran pemerintah Desa sangat signifikan dalam menjaga keteraturan, keselarasan, kerukunan antar warga Desa serta melakukan koordinasi terhadap lembaga-lembaga sosial keagamaan yang ada. Oleh karena itu, hubungan atau interaksi masyarakat harus dibangun atas norma-norma konvensional maupun legal formal, sehingga hubungan masyarakat dapat terjamin keharmonisannya dalam kehidupan bermasyarakat (Solekhan, 2012, hal. 41).

Dalam struktur pemerintahan Desa Manislor Kuningan, pemimpin atau kepala Desa adalah warga Ahmadiyah, sehingga posisi ini dapat menjadi jembatan bagus untuk proses rekonsiliasi tersebut lebih mudah terwujud. Sebagaimana tuturan bapak kepala desa:

"kepala Desa Manislor memang dari dulu adalah dari warga Ahmadiyah sendiri, namun tidak menutup kemungkinan adanya konflik yang menyerang Manislor. Ini bagi saya pribadi, saya memiliki tanggungjawab besar dalam melakukan koordinasi dan proses peredam konflik tersebut. Hal ini bukan saya sebagai kepala Desa yang kebetulan orang Ahmadiyah, akan tetapi saya sadar akan posisi saya sebagai kepala Desa yang berkewajiban menjadi jembatan atas kerukunan dan kenyamanan setiap warga di Desa ini." 
Lembaga ini menjadi sarana untuk saling memahami aktivitas keagamaan jemaat Ahmadiyah lewat peran elit-elitnya, karena komunikasi dan dialog yang terjadi dapat menjadi kekuatan dalam menumbuhkan sikap toleransi dan saling menghormati bukan hanya pada tataran konseptual semata, akan tetapi terwujud dalam ranah tindakan. Sehingga, pengendalian sosial yang bertujuan mencapai keserasian, kerukunan dapat terwujud dan terjalin hubungan sosial di antara masyarakat jema'at Ahmadiyah Manislor dan kelompok lain.

Beberapa ruang kegiatan sosial yang dibangun jemaat Ahmadiyah bertujuan untuk membentuk interaksi dan komunikasi yang nantinya akan terbentuk affective others, (Rakhmat, 1996, hal. 101). yaitu orang lain dengan mereka akan mempunyai ikatan emosional. Sehingga, dari situ seseorang membentuk konsep tentang dirinya, penghargaan, dan saling memiliki. Pola komunikasi seperti itu yang dibangun jem'at untuk dapat melebur di masyarakat.

\section{Open Understanding}

Jemaat Ahmadiyah saat peristiwa konflik tahun 2002-2010 masih menutup diri untuk menunjukkan akan paham kepercayaannya kepada khalayak umum. Inilah yang menjadi salah satu sebab akan terjadinya konflik yang berkepanjangan sampai hampir 10 tahun. Ketertutupan pamahaman kepada masyarakat tersebutlah yang menjadikan konflik terjadi. Sebagaimana penuturan salah satu muballigh dan ketua cabang, yakni Nashiruddin dan Nursalim bahwa:

"Penyerangan yang terjadi unsur utamanya adalah ketidakpahaman para ghair/mereka terhadap pemahaman kita (Ahmadiyah). Mereka hanya mengetahui Ahmdiyah dari berita-berita/ kabar burung, bukan mengetahui secara langsung dengan mata kepala mereka sendiri. Kita sering dibilang bahwa syahadat kita berbeda, shalat kita berbeda, dan ketika pergi haji kita bukan ke Makkah akan tetapi ke Qadian. Dari situ mereka berani menyerang kita. Dari hal tersebut, kita warga Ahmadiyah mencoba untuk menyelesaikan kesalahpahaman tersebut dengan mulai membuka diri terhadap warga masyarakat atas pemahaman Ahmadiyah yang sesungguhnya."

Dari situ, mayarakat Ahmadiyah Manislor mulai membuka diri dengan masyarakat untuk menyelesaikan konflik yang sedang terjadi. Mereka mendatangi para pemimpin keagamaan dan para pemimpin kelompok penyerang mereka untuk memberikan pemahaman tentang Ahmadiyah itu seperti apa. Melalui proses dialog ini maka konflik yang sering terjadi tersebut mulai mereda. Salah satu ghair Ahmadi menuturkan bahwa:

"Saat terjadinya konflik di Manislor, warga Ahmadiyah di sana, terutama pengurusnya mulai membuka diri, yakni dengan bersilaturrahmi ke tokohtokoh masyarakat, biasanya datang personal ke rumah masing-masing dan di sana mereka meminta saran untuk cara meredam konflik yang terjadi tersebut dan juga memberikan pemahaman atas paham Ahmadiyah yang sesungghnya. 
Saya juga memberikan saran kepada mereka untuk mendekati para tokoh masyarakat dan pemerintahan agar mereka paham apa itu Ahmadiyah.”

Proses membuka diri inilah yang dapat menjadi salah satu proses upaya rekonsiliasi yang dibangun dalam meredam konflik yang terjadi berkepanjangan.

\section{Simpulan}

Ada beberapa poin yang dapat disimpulkan: Pertama,bahwa konsep perdamaian telah menjadi pijakan hidup jema'at Ahmadiyah Manislor dalam menyelesaikan konflik yang terjadi. Itu sebabnya, mereka memilih cara-cara dialog dan rekonsiliasi, katimbang cara-cara kekerasan. Kedua, al-Qur'an telah diresepsi Jemaat Ahmadiyah dalam bentuk resepsi hermeneutis yang mencerminkan pemahaman yang kontekstual. Mereka dalam memahami ayat al-Qur'an bukan mempertimbangkan aspek literal teks, melainkan juga konteks historis masa Nabi dan kondisi yang dihadapi saat sekarang. Tidak berlebihan jika dikatakan bahwa jema'at Ahmadiyah sebenarnya telah menerapkan teori hermeneutik, meskipun secara metodologis belum sistematis. Pandangan ini dibuktikan dengan aksi-aksi konkret melalui upaya-upaya rekonsiliasi yang dilakukannya, yakni silaturrahmi kepada pemuka agama dan pemerintahan, juga melakukan kegiatan-kegiatan yang secara tidak langsung memberikan pemahaman kepada masyarakat tentang bagaimana sebenarnya paham Ahmadiyah.

Dari pemahaman ayat al-Quran tentang ayat jihad, jemaat Ahmadiyah Manislor membangun suatu pola interaksi yang bertujuan membangun konstruksi damai. Konstruksi bina damai yang dilakukan jemaat Ahmadiyah Manislor terwujud dalam beberapa faktor, yakni dalam kegiatan sosial, peran para elit pemerintahan Desa, hubungan kekeluargaan di antara mereka, baik yang Ahmadi dan non Ahmadi, dan juga open understanding. Pemahaman al-Qur'an akan konsep perdamaian berusaha diwujudkan dengan pola interaksi yang intens di antara mereka. Kegiatankegiatan bersama menjadi salah satu ruang publik terjalinnya ikatan emosional di antara mereka yang meredam konflik manifes destruktif. 


\section{Referensi}

Anderson, Stephen K. (1993). Sosiologi Makro: Sebuah Pendekatan terhadap Realitas Sosial, terj. Farid Wajidi, S. Menno. Jakarta: Rajawali Press.

Bashit, Abdul. (2013). Krisis Dunia dan Jalan Menuju Perdamaian. Jakarta: Neratja.

Echol, John M. dan Hasan Shadily. (2003).Kamus Inggris Indonesia. 2003. Jakarta: PT. Gramedia Pustaka Utama.

Idi, Abdullah. (2011). Bangka: Sejarah Sosial Cina Melayu. Yogyakarta: Tiara Wacana.

Jauss, Hans Robert.Toward an Aesthetic of Reception, terj. Timothy Bahty. Tth. Minneapolli: University of Minnesota Press.

Johansen, Robert C. (1997). Radical Islam and Nonviolence: A Case Study of Religious Empowerment and Constraint Among Pashtune.Journal of Peace Research 34(1).

King, Martin Luther. (1958). Stide Toward Freedom. New York: Harper and Row.

Lings, Martin. (1983). Muhammad: His Life Based on the Earliest Sources. Rochester, Vt Inner Traditions International.

Manzhur, Ibn .Lisan al-Aarab.

Nasikun.(1995). Sistem Sosial Indonesia. Jakarta: PT. Rahagrafindo Persada.

O'dea, Thomas F. (1996). Sosiologi Agama Suatu pengenalan Awal. Jakarta: PT. RajaGrafindo Persada.

Prawira,Kulman Tisna. (2012). Sejarah Desa Manislor. Kuningan: ttp.

Rakhmat, Jalaluddin. (1996). Psikologi Komunikasi. Bandung: Remaja Rosdakarya.

Ratna, Nyoman Kutha. (2006). Teori, Metode, dan Teknik Penelitian Sastra daro Strukturalisme hingga Postrukturalis Perspektif Wacana Naratif. Yogyakarta: Pustaka Pelajar.

Ritzer, George.Sociology: A Multiple Paradigm Science, terj. Alimandan. (1985). Jakarta: CV. Rajawali.

S, Ibrahim, A. Teori-teori Pengetahuan Modul Pengayaan Matakuliah Filsafat Ilmu Bahasa. Malang: Tidak Diterbitkan.

Sahiron dkk. (2012). Tradisi Islam dan Peradaban. Yogyakarta: Suka Press.

Schuon, Frithjof. (2003). Mencari Titik Temu Agama-Agama. Jakarta: Pustaka Firdaus. 
Soekanto, Soerjono. (1983). Beberapa Teori Sosiologi Tentang Struktur Masyarakat. Jakarta: Rajawali Press.

Solekhan, Moh. (2012). Penyelenggara Pemerintahan Desa. Malang: Setara Press.

Syahrur, Muhammad. (2008). Tajfif Manabi`al-Irhab. Damaskus: al-Ahali.

Syamsuddin, Sahiron. (2011). Hermeneutika dan Pengembangan Ulumul Quran. Yogyakarta: Pesantren Nawesea Press.

T, Seger Rien.The Evolution of Texts. Lisse: The Peter de Ridder Press.

Tim Jemaat Ahmadiyah. (2004). al-Qur'an Terjemah dan Tafsir Singkat, terj. Dewan Naskah Jemaat Ahmadiyah. Jakarta: Neratja.

Zulkarnain, Iskandar. (2011). Gerakan Ahmadiyah di Indonesia. Yogyakarta: LkiS.

Rafiq, Ahmad. (2015). The Joy of the Scripture: Claiming the Past in Contemporary Reception of the Quran in Indonesia.International Conference.

Wawancara dengan Muballigh Nashiruddin.

Wawancara dengan Muballigh Aang.

Wawancara dengan Muballigh Hendri.

Wawancara dengan Ketua Cabang Nursalim.

Wawancara dengan Kepala Desa Yusup Ahmadi.

Wawancara dengan Kyai Pesantren Memet.

Wawancara dengan Ketua Wilayah Khuddam Pak Wahyudi.

Wawancara dengan warga NU Bu Ooh. 